\title{
PROCEEDINGS
}

OF THE

\section{EDINBURGH MATHEMATICAL SOCIETY}

\section{CONTENTS}

D. G. WEIR: The Propagation of a Constant Strength Shock through a Simple Wave

page 277

E. DEUTSCH: Evaluation of Certain Integrals Involving Bessel Functions

page 285

c. G. CHEHATA: Existence Theorem for Groups

ЈонN S. PYM: A Note on the Kawada-into Theorem

P. SмIтH: An Example of a Plane Shock of Variable Strength

J. c. cOoKE: Some Further Triple Integral Equation Solutions

W. E. WILliams: Integral Equation Formulation of some Three Part Boundary Value Problems

F. M. RAGAB: The Laplace Transform of the Modified Bessel Function $K\left(t^{ \pm m} x\right)$ where $m=1,2,3, \ldots, n$

page 291

page 295

page 297

page 303

page 317

page 325

R. A. RANKIn: The Difference between Consecutive Prime Numbers $\mathbf{V}$

page 331

F. HARARY AND A. HILl: On the Number of Crossings in a Complete Graph

page 333

BOOK REVIEWS

page 339

MATHEMATICAL NOTES

E. SPENCE: Formulæ for Sums Involving a Reduced Set of Residues Modulo $n$

page 347

K. N. SRIVAstava: Dual Integral Equations with Bessel Function and Trigonometrical Kernels

page 351

\section{OLIVER AND BOYD}

EDINBURGH : TWEEDDALE COURT

LONDON : 39A WELBECK STREET, W.1 


\section{THE EDINBURGH MATHEMATICAL SOCIETY}

The Edinburgh Mathematical Society was instituted in 1883 for the promotion and extension of Mathematical Science-Pure and Applied.

Candidates for membership are nominated at one Ordinary Meeting of the Society and the candidature is voted upon at the next, a majority of at least two-thirds of the members present being necessary for election. Ordinary Members pay subscriptions to the funds of the Society at the times and of the amounts specified in the Rules. Members whose subscriptions are not in arrears receive free of charge one copy of each of the Society's publications. Additional copies and back numbers - as far as these are in print-are charged at a discount on the published price. Further information regarding membership may be obtained from the Secretary.

\section{PROCEEDINGS OF THE EDINBURGH MATHEMATICAL SOCIETY AND THE EDINBURGH MATHEMATICAL NOTES}

The Society publishes the Proceedings of the Edinburgh Mathematical Society which contains papers embodying the results of research that is original in matter or manner and a section entitled Notes containing material of a less specialised nature. Members of the Society may submit papers for consideration with regard to publication; papers from non-members can be communicated by a member. Manuscripts of papers received cannot be accepted if not in a form suitable for submitting to the printer. Authors are advised to retain a copy of anything they may send for publication as the Society eannot accept responsibility for any loss. Manuscripts of papers for publication should be sent in the first instance to the Secretary.

Series I of the Proceedings consists of forty-four volumes published from 1886 to 1926. Series II consists of twelve complete volumes to date.

The Proceedings are published in parts and issued twice yearly. Four parts complete a volume of approximately 200 pages, and the Title Pages and Index are published in part 4 of each volume.

The prepaid subseription per volume is 60 s. (U.S.A. and Canada $\$ 10.00$ ) post free. Single parts $15 \mathrm{~s}$. (U.S.A. and Canada \$2.50) net. Orders, and requests for prices and availability lists of in-print back numbers, should be addressed to the publishers,

\section{Oliver and Boyd \\ Tweeddale Court \\ 14 High Street \\ Edinburgh 1}

The Secretary will be pleased to receive gifts of back numbers of the Proceedings as certain of these are scarce and there is a demand from libraries for them.

All communications concerning the Library should be addressed to

The Librarian

The Edinburgh Mathematical Society

20 Chambers Street

Edinburgh 1

All other communications should be addressed to

The Secretary

The Edinburgh Mathematical Society

20 Chambers Street

Edinburgh 1 


\section{PROCEEDINGS}

OF THE

EDINBURGH MATHEMATICAL SOCIETY 


\title{
PROCEEDINGS
}

OF THE

\section{EDINBURGH MATHEMATICAL SOCIETY}

\author{
EDITED BY \\ I. N. SNEDDON \\ J. HUNTER G. MACKENZIE
}

VOLUME 13 (SERIES II)

$1962-1963$

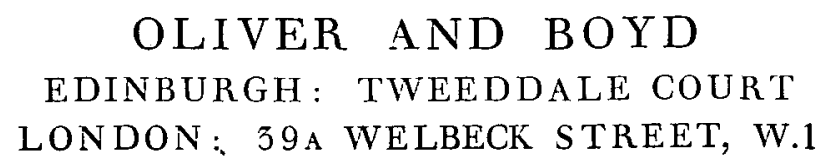




\section{COPYRIGHT (C) 1961 THE EDINBURGH MATHEMATICAL SOCIETY}

PRINTED AND PUBLISHED IN GREAT BRITAIN BY OLIVER AND BOYD LTD., EDINBURGH 


\section{CONTENTS}

AITKEN, A. C. Note on a difference-product inequality

BOOK REVIEWS

$115,191,255,339$

BOWDEN, N. A. On the zeros of a class of canonical products of integral order

BURLAK, J. A pair of dual integral equations occurring in diffraction theory

CHEHATA, C. G. Embedding theorems for groups

CHEHATA, C. G. Existence theorem for groups

COHEN, ECKFORD. An analogue of a result of Jacobsthal

COLlins, W. D. On the solution of some axisymmetric boundary value problems by means of integral equations. VII. The electrostic potential due to a spherical cap situated inside a circular cylinder

COLlins, W. D. On the solution of some axisymmetric boundary value problems by means of integral equations. VIII. Potential problems for a circular annulus

COLlins, W. D. Some axially symmetric stress distributions in elastic solids containing penny-shaped cracks. III. A crack in a circular beam

COOKE, J. C. Some further triple integral equation solutions

COXETER, H. S. M. The abstract group $G^{3,7,16}$

COXETER, H. S. M. The abstract group $G^{3,7,16}$ : a correction

DA VIES, I. J. Enumeration of certain subgroups of Abelian p-groups

DEUTSCH, E. Evaluation of certain integrals involving Bessel functions

DIANANDA, P. H. A cyclic inequality and an extension of it. I.

DIANANDA, P. H. A cyclic inequality and an extension of it. II.

EASON, G. Thermal stress in anisotropic cylinders

ETHERINGTON, I. M. H. Note on quasigroups and trees

GEORGE, D. L. Numerical values of some integrals involving Bessel functions 
HARARY, F. AND HILL, A. On the number of crossings in a complete graph

HILL, A. See Harary, F. and Hill, A.

INGRAM, W. H. The $j$-differential and its integral

JACK, HENRY. An application of the addition theorem for determinants

165

JACK, HENRY. An integral over the interior of a simplex

LESLIE, F. M. The motion of a flat plate from rest in a visco-elastic liquid

LOWENGRUB, M. AND SNEDDON, I. N. An axisymmetric boundary value problem of mixed type for a half-space

LOWNDES, J. S. Parseval relations for Kontorovich-Lebedev transforms

MACDONALD, I. D. On central series

MARTIN, M. H. Some aspects of uniqueness for solutions to boundary problems

MERCER, A. MCD. On integral transform pairs arising from second order differential equations

MAXFIELD, JOHN E. AND MINC, HENRYK. On the matrix equation $X^{\prime} X=A$

MINC, HENRYK See Maxfield, John E. and Minc, Henryk

OBITUARY NOTICE: H. W. Turnbull

PYM, JOHN S. A note on the Kawada-into theorem

RAGAB, F. M. The Laplace transform of the modified Bessel function $K\left(t^{ \pm m} x\right)$ where $m=1,2,3, \ldots, n$

RANKIN, R. A. The difference between consecutive prime numbers V 331

SMITH, P. An example of a plane shock of variable strength

SNEDDON, I. N. See Lowengrub, M. and Sneddon, I. N.

WATSON, G. N. A proof of Kirkman's hypothesis

WEIR, D. G. The propagation of a constant strength shock through a simple wave

Williamson, J. H. The Wiener-Pitt phenomenon on the half-line

WILLIAMS, W. E. Integral equation formulation of some three part boundary value problems

WOUK, ARTHUR: An algebraic problem in control theory

The Edinburgh Mathematical Notes appear at the end of each part 